\title{
Correction to: Strictly elliptic operators with generalized Wentzell boundary conditions on continuous functions on manifolds with boundary
}

\author{
Tim BinZ
}

Correction to: Arch. Math. 115 (2020), 111-120

https://doi.org/10.1007/s00013-020-01457-0.

The article "Strictly elliptic operators with generalized Wentzell boundary conditions on continuous functions on manifolds with boundary" written by Tim Binz was originally published Online First without Open Access. After publication in volume 115, issue 1, pages (111-120), the author decided to opt for Open Choice and to make the article an Open Access publication. Therefore, the copyright of the article has been changed to (C)The Author(s) 2020 and the article is forthwith distributed under the terms of the Creative Commons Attribution 4.0 International License, which permits use, sharing, adaptation, distribution and reproduction in any medium or format, as long as you give appropriate credit to the original author(s) and the source, provide a link to the Creative Commons licence, and indicate if changes were made. The images or other third party material in this article are included in the article's Creative Commons licence, unless indicated otherwise in a credit line to the material. If material is not included in the article's Creative Commons licence and your intended use is not permitted by statutory regulation or exceeds the permitted use, you will need to obtain permission directly from the copyright holder. To view a copy of this licence, visit http://creativecommons. org/licenses/by/4.0. 
The original article has been corrected.

Publisher's Note Springer Nature remains neutral with regard to jurisdictional claims in published maps and institutional affiliations.

\section{Tim BinZ}

Department of Mathematics

University of Tübingen

Auf der Morgenstelle 10

72076 Tübingen

Germany

e-mail: tibi@fa.uni-tuebingen.de 